\title{
Exploration of innovation and entrepreneurship education mode of College Students under the background of informatization
}

\author{
Chen Qing \\ Shaanxi Xueqian Normal University, Shaanxi Xi'an, 710100
}

Keywords: Information background, College students, Entrepreneurship.

\begin{abstract}
For contemporary college students, entrepreneurship is not a particularly strange word. Nowadays, college students are in the electronic information age, many college students have started their own business projects, and accumulated a lot of experience in the business process, so as to promote the ability of independent innovation in china. Major universities have also paid a lot of efforts in entrepreneurship education, to a certain extent, promoted the future development of students.
\end{abstract}

\section{Introduction}

Today, people entered the information age, the rapid development of network communication technology with the traditional way, students' beliefs and learning have undergone great changes, the students not only learn the theoretical knowledge in the classroom practice, but also deep into the life and work of a large number of students, the use of the Internet can be skilled. Accept the entrepreneurial education more rich and colorful. The teacher in the teaching process, students can be guided by the Internet full of entrepreneurial learning experience, through multimedia playing some successful experiences of entrepreneurship, entrepreneurship to the autonomy of the students can be aroused. And the teacher can also use network to build a platform for the exchange of information, students can according to business problems on this platform will speak freely, the problems and difficulties of entrepreneurship are discussed, which can focus on solving practical problems of students of entrepreneurship.

\section{The educational connotation of innovation and entrepreneurship under the background of} informatization

Today, mankind has entered a new era of technological revolution, promote people's production and life style transformation, in the agricultural revolution and the industrial revolution, people are now facing the technology revolution, information technology and communication technology to achieve high-speed development, can improve the information processing technology, make people into a new era. The development of information technology to enhance the people's cognitive ability in a certain extent, the more complicated things can be in a more direct way to show in front of people's value, make some complicated work becomes simple. With the rapid development of information technology and network technology, the traditional mode of entrepreneurship education has also undergone great changes. The Internet has made great changes in traditional education channels. Entrepreneurship is a kind of innovative activity, which can create something new and valuable, and it is of great value to enterprise furniture. Today, entrepreneurship has modern significance, which is the main business as much as possible to meet the requirements of their own, using advanced knowledge and information exchange means, improve the innovation ability, create more performance.

In the process of education for college students, innovation is not only product innovation, but also service innovation, enterprises through the formulation of relevant systems and marketing 
models, improve the concept of innovation. In the process of entrepreneurship, innovation is an important driving force, innovative methods and means determine whether the road of entrepreneurship is smooth, innovation can make the road of entrepreneurship more smoothly, and the process of innovation is also the process of entrepreneurship. Contemporary college students should take the initiative to accept innovation and entrepreneurship education model, colleges and universities should improve their innovative ability and entrepreneurial literacy, so as to lay a solid foundation in the future of independent innovation[1].

\section{The significance of College Students' innovation and Entrepreneurship Education under the background of informatization}

In the process of national development, college students play a very big role. In college, students' learning environment is very good, and there are abundant learning resources in universities, their thinking is very active, it can have some theoretical knowledge, which plays a very important role in the national innovation. College students play an important role in the development of the country, and bear the great mission to realize the development of an innovative country. Therefore, colleges and universities should continue to promote the thinking of college students and train their thinking ability and innovative ideas in teaching.

Nowadays, college students are in the era of knowledge economy. In the process of accepting college education, there are also many differences between the new teaching mode and the traditional teaching mode. Moreover, college students accept some new ideas, they pursue individual liberation, and they have the courage to innovate in their study. They can show their self-consciousness and realize their self-worth in their work. In the development of the job, the students in the background of the knowledge age have definite goals, their life ideal is very ambitious, and hope to realize their value in the suitable position. Therefore, today's College Students' entrepreneurship education and traditional education show obvious differences, and they pay more attention to the cultivation of comprehensive ability of college students, and improve the cultivation of College Students' independent consciousness. Improve the innovative ability of college students, so that students can accept the training of entrepreneurship education knowledge, can further enhance the overall quality of College students[2].

In 2014 alone, the number of Chinese college graduates as many as about 7000000 people, the number of college graduates increased, which led to the employment competition is more intense, resulting in China's college graduates is difficult to find a suitable job. In the face of the severe employment situation, should actively carry out entrepreneurship and employment of college students in education, have a certain entrepreneurial ability, it can establish a more lofty ideals, to perfect the employment concept, talent shows itself in the social competition.

With the continuous improvement and development of China's socialist market economy, the structure of China's urban and rural industries has also undergone certain changes. Along with the market economy unceasing adjustment, college students are faced with severe challenges in the employment process, only with new knowledge and new technology, in order to create more value for the enterprise, students can become scarce talent market. Therefore, colleges and universities should pay attention to the development of college students, provide them with innovative and entrepreneurial education, so that college students can better adapt to the needs of the job market and increase their chances of employment. In today's rapid development of information technology, various types of industrial development is very rapid, the needs of social development in all aspects of personnel, but also need to promote the innovative concept of the development of the market, in order to meet the market economy gap in a certain extent. Now, the speed of information dissemination is very fast, the means of dissemination is also very advanced, college students want to learn more information, should make their resources are fully utilized, to grasp the direction of development of the market. Have a specific understanding of the newly issued national policy, this is the education of creation and innovation of college main purpose, just rely on College efforts will not enable students to understand the social reality, creation and innovation of college students through the school and the society should help achieve[3]. 


\section{The path of innovation and entrepreneurship education of College Students under the background of informatization}

Today, college students make full use of the Internet to update their ideas, acquire a large amount of knowledge, and improve their learning and communication. The network meets the psychological needs of college students to a certain extent, and it has perfected the function of value orientation. Therefore, colleges and universities should make full use of the Internet to promote the innovation and entrepreneurship education of college students, so that their awareness of entrepreneurship can be improved. First, universities can spread some innovation and entrepreneurship education in their website knowledge, through the BBS, to enable students to use their mobile phone to regular education, establish the perfect base for innovation and entrepreneurship education network. Universities can use the Internet, through all kinds of rich and colorful activities, regular lectures and competition, to enable students to further enhance the cognitive ability of innovation and entrepreneurship education, so that students can understand more fully the relevant practice activities. Second, get a lot of resources in Colleges and universities should fully use the network, we can learn from some successful cases of innovation and entrepreneurship education in the network, and according to their actual situation, stimulate students' entrepreneurial autonomy. Through the Internet to create a platform for communication and education, and to achieve cooperation with the forum, so as to communicate the experience of entrepreneurship, share the experience of entrepreneurship, so that the entrepreneurial awareness of college students to be nurtured[4].

In college students, the previous successful experience can help them find business methods as soon as possible, but also through some successful cases to encourage college students into self employment, however, if only rely on the experience of predecessors, so college students thinking will be subject to certain restrictions, that they can't start in my own way. Proof of the practice, many college students in the business process, they can not fully understand the social situation, in the choice of entrepreneurial projects very blind, they tend to experience too much of the previous reference. In this context, colleges and universities should improve the cultivation of College Students' entrepreneurial thinking, encourage students to adopt different ways of entrepreneurship, so as to prevent the successful experience of predecessors from being used for reference. Now, in China's first tier cities, entrepreneurship development basically saturated situation, colleges and universities should guide students in the second or three line of urban development, so that students' entrepreneurial rate has been improved. In the selection process of entrepreneurial projects, students should pay more attention to some emerging industries, which can be developed in the service industry and so on, so that their own entrepreneurial success rate will increase.

Today, the network develops very quickly, the students generally use the network of entrepreneurship, which can effectively save the cost of entrepreneurship, entrepreneurship to make up for the shortage of funds, but also enable students to accumulate rich experience in the business process, business students very trust on the network. For college students, as long as they are familiar with the network environment, and familiar with computer operation, you can open a shop on the Internet, this form can save large sums of venture capital, and the students at any time and place can open shop, is the best choice for college students entrepreneurship. The risk of opening an online store is much smaller than that of a physical store. College students can start their business on some large portals. Compared with the traditional way of entrepreneurship, the threshold of network entrepreneurship is lower, and the prospect of entrepreneurship is relatively broad.

Now, many colleges and universities are in the process of entrepreneurship education, their teachers are poor, high-quality teachers are lacking. In order to solve the above problems effectively, colleges and universities can combine other colleges and universities and adopt online education and training methods to enable students to accept online courses. Online entrepreneurship education is spreading fast, and students can receive education at any time and place without having to occupy a large number of classrooms. Students can use their mobile phones and tablet computers to receive online education, and they can choose their own online courses to make their learning more 
effective. Colleges and universities should carry out online education curriculum development, and use the Internet to show themselves in front of college students, so as to create better network entrepreneurship education environment for colleges and universities. Colleges and universities can also use some classic cases to make it in the form of a complete document, so that students can read systematically[5].

In the course of teaching, universities should pay more attention to network education from the point of view of ideology. Even under the background of the information age, even if college students do not start their own businesses, they should also understand the relevant knowledge of entrepreneurship. The means of information technology has penetrated into every aspect of students' learning. In the process of entrepreneurship education, it is not a very distant thing for students to realize that entrepreneurship is not a very distant thing. As long as students have the idea of innovation, they can try to start a business. Many students have been engaged in derivative industry, with the help of the Internet business, the entrepreneurial environment do not need to pay too much money, as long as their own efforts, to establish the correct business philosophy, can be harvested in the process of entrepreneurship, and have fun.

For innovation and entrepreneurship education in Colleges and universities in the link, can not continue to use the traditional teaching methods, students in learning, can not just stay on the books of knowledge learning, innovation education should also be continuous mode, college teachers should take the initiative to lead students to practice, to understand the local enterprises, and carry out some practice the activities of the students, with the help of the Internet can be timely communication with the teacher. By way of live webcast, teachers and students can have direct interaction with students at different times and places.

In the process of innovation and entrepreneurship education, teachers should pay attention to stimulate students thinking, make their thinking broaden, create a good business environment for the students, for they can show their ability to create a platform. So that they understand the integration model of entrepreneurship at the University during this session, the university should improve the enterprise's cooperation, can invite some successful entrepreneurs to the speech about their entrepreneurial experience, so that students can seriously handle the transaction in the business platform, develop their creative thinking, and full play their expertise, achieve their own[5].

\section{Conclusion}

In the process of College Students' innovation and entrepreneurship education, the ultimate aim is to improve the innovative consciousness and creative ability of college students, and to train more complex talents for the country. College students are the main population of entrepreneurship in China, and the cultivation of innovative ability of college students can promote the development of the country and the stability of society. Colleges and universities should attach great importance to the promotion of students' ability to start an undertaking. On the basis of building socialism with Chinese characteristics, we should improve the mode of innovation and entrepreneurship education so as to improve the rate of entrepreneurship for college students in china.

\section{References}

[1]Kai L I, Yang Y S. Survey on the New Ways to Enhance College Students' Entrepreneurship Education under Conditions of Informatization[J]. Journal of Guangdong Technical College of Water Resources \& Electric Engineering, 2012.

[2]Zhang L, Zhang L. Application and Practice of Information Technology under the Project Management of College Student' s Innovative and Entrepreneurial Training Program[C]// International Conference on Cultivating Undergraduate Entrepreneurship and Management Engineering. 2015.

[3]Liu G, Sun S, University Y. Strategies of College Students' Entrepreneurship Education and Training in Informatization Age[J]. Office Informatization, 2014. 
[4]Xia-Xia N I, University F J. Exploration on the new mode of College Students' innovation and Entrepreneurship Education[J]. Journal of Hunan City University, 2016.

[5]Ren C. Exploration of Innovative and Entrepreneurial Talents Cultivating Mode for Electronic Business Specialty in Application-oriented Colleges and Universities[J]. Office Informatization, 2016.

Supported by 1、 The Social Science Foundation of Shaanxi Province of China (Grant No. 2016P004)2、Scientific Research Foundation of Education department of Shaanxi Provincial Government of China (Grant No. 16JK1177)。 